\title{
Quality Characteristics of Salted Egg Soaked with Aloe vera Solution
}

\author{
Deni Novia ${ }^{\#}$, Indri Juliyarsi ${ }^{*}$ \\ \# Department of Technology of Livestock, Animal Science Faculty, Universitas Andalas, Padang, Indonesia \\ E-mail:dnovia@ansci.unand.ac.id; indrijuliyarsi@ansci.unand.ac.id
}

\begin{abstract}
Aloe vera contains unique compounds, including antioxidants. However, it also contains oxidase, which accelerates the oxidation process, in addition to aloin, saponins, amino acids, hormones, minerals, glucomannans, and other compounds. This research was aimed at producing raw salted eggs with herbal effects using a blanching process and marination in different concentrations of aloe vera solution as well as an analysis of the nutritional value, $\mathrm{NaCl}$ content, total phenolic content, antioxidant activity, albumen pH, and total plate count of raw salted eggs. This study used a randomized complete block design with three replications in a $3 \times 2$ factorial. Factor $A$ is blanching treatment, and factor B is the Aloe vera solution. Based on the analysis, it was found that there were significant interactions between blanching and the different concentrations of Aloe vera solution that increased the protein content, total phenolic content, and antioxidant activity and decreased the albumen $\mathrm{pH}$ and total plate count. The best treatment was the 14\% Aloe vera solution without blanching.
\end{abstract}

Keywords-Aloe vera solution; blanching; nutritional value; raw salted eggs; total phenolic content.

\section{INTRODUCTION}

Salted eggs are one of the traditional snacks of West Sumatra, specifically in Sicincin, and are made by placing duck eggs in a salt solution using ash and salt for 3 to 5 days, producing a distinctive taste that is liked by many people. This is in line with the results of research done by Novia, in which marinating duck eggs utilizing ash can increase the mineral content of salted eggs by salting for eight days [1]. The salting process might take longer. Also, to extend the shelf life of salted eggs, a preservation process can be performed. Soaking in salted gambier liquid waste for 1 hour can extend the shelf life of salted eggs by up to 63 days [2].

Other salted eggs that have been widely studied are have included herbal effects by adding ginger, white turmeric, cinnamon, garlic oil, and aloe vera. Suryatno researched salted eggs with the addition of $50 \%$ ginger extract in the salting process and showed that this could improve the antioxidant activity, total phenolic content, and preferability according to panelists [3]. Andriyanto examined the addition of $5 \%$ cinnamon extract, which was most preferred by panelists and had the highest antioxidant activity. An increase in the concentration led to a decrease in the antioxidant activity and sensory characteristics of salted eggs [4]. Chemical components of aloe vera include vitamins, enzymes, minerals, sugars, anthraquinones, sterols, salicylic acid, and amino acids [5].

Some advantages of aloe vera are as follows: as an alternative natural preservative [6]; for improving the quality of low-quality ground beef [7]; for its potential use as an edible coating material [8]; for use in supplements that are safe and effective [9]; as an extract that contains higher antioxidant properties than the synthetic antioxidant BHT, tocopherol and ascorbic acid [10], [11]; as a source of the antioxidant superoxide dismutase, which has been used to treat induced-diabetes Wistar rats [12]; for its potential as an antibacterial and antifungal agent [13], [14]; as a source of acemannan, which effectively reduces pain and speeds the healing of wounds [15]; and for potential anticancer activity [16]. Aloe vera is composed of chemical components that are complete. According to Luta and McAnalley, the dry weight in Aloe Vera gel was composed of $55 \%$ polysaccharides, $17 \%$ sugar, $16 \%$ minerals, $7 \%$ protein, $4 \%$ fat, and a total phenolic content of $1 \%$ [17].

However, Aloe Vera also contains antinutrient compounds such as aloin and saponins and must be heated to $80^{\circ} \mathrm{C}$ and extracted over 60 minutes to remove antinutrient inhibiting substances and increase the antioxidant activity [18]. Making salted eggs using 50\% aloe vera solution can extend the shelf life of cooked salted eggs for 19 days [19]. The purpose of this research is to produce salted eggs with effects using blanching and aloe solutions of different concentrations in the process of salting and to examine the quality characteristics of salted egg such as nutritional value, $\mathrm{NaCl}$ content, total phenols, antioxidant activity, albumen $\mathrm{pH}$, and total plate count of raw salted eggs. 


\section{MATERIAL AND METHOD}

This study used Tegal (Anas javanica) duck eggs with a bluish-green eggshell, aged up to 48 hours. As many as 180 eggs weighing 65-70 grams were obtained from duck breeders in Piai, Padang city, Indonesia. The instrumentation used during this research included an $1800 \mathrm{UV}-\mathrm{V}$ is spectrophotometer, filters, Whatman filter paper, a pH meter, a laminar air flow, an incubator, and a colony counter.

The experimental method used was a randomized block design with Two ways Anova Factorial $2 \times 3$ and three replications. Factor A is blanching treatment, and factor B is the aloe vera solution. If the results of variance were significant, the effect was further tested using Duncan's test. The parameters measured were the nutritional value, $\mathrm{NaCl}$ content, total phenolic content, antioxidant activity, albumen $\mathrm{pH}$, and total plate count of the raw salted eggs. The research was conducted at the Laboratory of Livestock Product Technology, Animal Husbandry Faculty, Andalas University.

The process of making salted eggs was as follows. 1) The meat of the aloe leaf was washed and cut into small pieces. Then, water was added at room temperature (without blanching / A1) with different concentrations of aloe vera (factor B: 2, 8, and 16\% solutions) and blended. Afterward, the solution from each treatment was divided in half and blanched ( $80^{\circ} \mathrm{C}, 15$ minutes) (A2). 2) The liquid aloe vera salting material was mixed with rice husk ash and salt with ratio 26:1:5. 3) The clean duck eggs with a maximum age of 2 days and weights of 65-75 $\mathrm{g}$ were soaked in the aloe vera salting solution (1:1.2) for nine days in $28-30^{\circ} \mathrm{C}$ (in room temperature). 3) The whole raw salted eggs were analyzed for nutritional value, total plate count, and eggs yolk for total phenolic content, antioxidant activity, then albumen for $\mathrm{NaCl}$ content, albumen $\mathrm{pH}$.

The nutritional value test consists of protein content by the Kjeldahl method, fat content by Soxhlet method, moisture content using oven method, ash content with the temperature of $550^{\circ} \mathrm{C}, \mathrm{NaCl}$ content by Argentometric Mohr, $\mathrm{pH}$ [20]. The total phenolic content was determined according to Velioglu using Folin-Ciocalteu reagents and the solvent used was $90 \%$ ethanol and $90 \%$ methanol while the antioxidant activity was measured using the modified method of Lu and Lai [21] and total plate count using pour plate method [22].

\section{RESULTS AND DISCUSSION}

\section{A. Nutritional Value and $\mathrm{NaCl}$ Content of Raw Salted Egg}

The proximate composition and $\mathrm{NaCl}$ content of raw salted eggs with blanching and different concentrations of aloe vera solution according to the levels of moisture, protein, fat, and ash is shown in Table 1. The variance analysis result shows that there was the interaction between blanching and different concentrations of aloe solution that affected the protein, fat and ash content of the raw salted eggs, but there was no real effect on the moisture and $\mathrm{NaCl}$ content.
TABLE I

NutRITIONAL VALUE AND $N A C L$ CONTENT (\%) OF RAW SALTED EgGS

\begin{tabular}{|c|c|c|c|c|}
\hline \multirow{2}{*}{$\begin{array}{l}\text { Factor } \\
\text { A }\end{array}$} & \multicolumn{3}{|c|}{ Factor B } & \multirow[t]{2}{*}{ Mean } \\
\hline & B1 & B2 & B3 & \\
\hline \multicolumn{5}{|c|}{ Protein content } \\
\hline A1 & $11.83 \pm 0.25^{\mathrm{bc}}$ & $11.95 \pm 0.13^{\mathrm{a}}$ & $12.41 \pm 0.56^{\mathrm{a}}$ & $12.04 \pm 0.30$ \\
\hline $\mathrm{A} 2$ & $10.80 \pm 0.17^{\mathrm{d}}$ & $10.01 \pm 0.17^{\mathrm{e}}$ & $11.34 \pm 0.07^{c}$ & $10.72 \pm 0.36$ \\
\hline Mean & $11.32 \pm 0.73$ & $10.98 \pm 1.37$ & $11.88 \pm 0.75$ & \\
\hline \multicolumn{5}{|c|}{ Fat content } \\
\hline $\mathrm{A} 1$ & $16.70 \pm 0.22^{c}$ & $\begin{array}{c}19.74 \pm 0.1 \\
5^{\mathrm{a}} \\
\end{array}$ & $16.80 \pm 0.56$ & $17.75 \pm 1.73$ \\
\hline $\mathrm{A} 2$ & $18.33 \pm 0.74^{b}$ & $\begin{array}{c}18.78 \pm 0.4 \\
6^{\mathrm{b}}\end{array}$ & $19.64 \pm 0.71$ & $18.91 \pm 0.66$ \\
\hline Mean & $17.51 \pm 1.15$ & $\begin{array}{c}19.26 \pm 0.6 \\
8 \\
\end{array}$ & $18.22 \pm 2.00$ & \\
\hline \multicolumn{5}{|c|}{ Moisture content } \\
\hline A1 & $69.62 \pm 1.91$ & $62.41 \pm 4.47$ & $69.12 \pm 0.73$ & $67.05 \pm 4.03$ \\
\hline $\mathrm{A} 2$ & $64.89 \pm 6.37$ & $60.78 \pm 2.44$ & $60.71 \pm 0.59$ & $62.13 \pm 2.40$ \\
\hline Mean & $67.26 \pm 3.34$ & $61.59 \pm 1.15$ & $64.91 \pm 5.95$ & \\
\hline \multicolumn{5}{|c|}{ Ash content } \\
\hline $\mathrm{A} 1$ & $2.09 \pm 0.25^{\mathrm{c}}$ & $\underset{\mathrm{bc}}{2.28 \pm 0.23}$ & $1.78 \pm \underset{\mathrm{d}}{ \pm 0.14}$ & $2.02 \pm 0.25$ \\
\hline A2 & $2.40 \pm 0.21^{\mathrm{bc}}$ & $2.52 \pm 0.17$ & $\underset{\mathrm{a}}{3.09 \pm 0.07}$ & $2.67 \pm 0.37$ \\
\hline Mean & $2.24 \pm 0.22$ & $2.40 \pm 0.17$ & $2.44 \pm 0.93$ & \\
\hline \multicolumn{5}{|c|}{$\mathrm{NaCl}$ content } \\
\hline A1 & $3.96 \pm 0.09$ & $4.86 \pm 0.72$ & $5.32 \pm 0.55$ & $4.71 \pm 0.69$ \\
\hline $\mathrm{A} 2$ & $4.99 \pm 0.40$ & $5.08 \pm 0.34$ & $5.62 \pm 0.23$ & $5.23 \pm 0.34$ \\
\hline Mean & $4.47 \pm 0.73^{b}$ & $4.97 \pm 0.15^{\mathrm{ab}}$ & $5.47 \pm 0.22^{\mathrm{a}}$ & \\
\hline
\end{tabular}

\section{1) The Protein Content}

Based on Table 1, the protein content of raw salted eggs was between $10.01 \pm 0.17$ and $12.41 \pm 0.56 \%$. The Duncan's test results indicated a significant difference by treatments A1B3, A1B1, A2B1, A2B2 and A2B3 and no significant difference from treatment $\mathrm{A} 1 \mathrm{~B} 2$. This indicated that the without blanching and the higher the aloe vera concentration used in the salting process, the higher the protein content of the raw salted eggs produced. In eggs produced by the A1B3 treatment, the protein content was the highest at $12.41 \pm 0.56 \%$. This was because the treatments without blanching allowed proteases to remain active in synergy with glucomannans, which were maintained in more significant numbers (14\% aloe vera solution). 
According to Kumar and Yadav, aloe vera contains proteases [23]. Polysaccharides in aloe stimulate proteins to enter the bacterial membrane, hollowing and damaging the layer protecting the inner fluid and causing the death of the bacteria [24]. The protein content of salted eggs increased by $1.02 \%(8.94 \pm 0.02$ to $9.96 \pm 0.05 \%$ with the addition of $40 \%$ white turmeric concentrate, in line with the antioxidants and polyphenols but salinity decreased [25]. Also, the aloe vera solution still contains aloin as an antibacterial agent. According to Agarwal and Sharma, aloin has potential as an antimicrobial agent [26]. Aloe vera also contains protein amounting to $6.86 \%$ of the dry weight of aloe vera extract [27]. Furthermore, Wardani said that the addition of aloe vera in the manufacturing of cow's milk prevents protein decline [28].

The blanching treatment with an aloe vera concentration of $8 \%$ (A2B2) had the lowest protein content but the highest $\mathrm{pH}$. The protein content of salted eggs produced with different salt concentrations yielded the lowest protein content of $11.8 \%$ from using only ash without salt added [29]. The blanching process inactivates the proteases and inhibits aloin and saponins. The heating of aloe vera to a temperature of $80^{\circ} \mathrm{C}$ for 60 minutes will inhibit aloin [18].

\section{2) The fat content}

The fat content results ranged from $16.70 \pm 0.22$ to $19.74 \pm 0.15 \%$. The Duncan's test results indicated that the A1B3 treatment had no significant effect compared to the A1B1 treatment, but had significantly different effects compared to that of other treatments.

The inclusion of aloe vera solution in the blanching process causes an increase in the fat content of raw salted eggs along with the increasing concentration of aloe vera. Saponins are inactivated upon heating aloe vera to a temperature of $80^{\circ} \mathrm{C}$ [18]. The optimum fat level was achieved from the A1B2 treatment without blanching, and no significant differences were observed with A2B3 treatment.

The lower fat content of treatment A1B3 and A1B3 probably contributed by the higher moisture content of the samples $(66 \%)$ compare other treatments $(60-62 \%)$. The fat levels from treatment A1B1 (without blanching, 2\% aloe vera concentration) were the lowest at $16.70 \pm 0.22 \%$. This concentration effectively produced salted eggs with low-fat content. This was caused by using the aloe vera solution without heating so that the lipase was not damaged and remained active in the outlying fat. Aloe vera contains lipase, which is influenced by the content of $\mathrm{Ca}$, which activates lipase in the salting solution [24]. The biological activity of aloe vera includes the breakdown of fat by enzymes, namely, alkaline phosphatase, amylase, alliinase, carboxypeptidase, catalase, cellulase, lipase, and peroxidase [30]. Saponins in aloe vera cause the saponification of fats, which will affect the fat content [23], [31]. In line with this, Agarwal and Sharma said that saponins are soapy substances with both cleansing and antiseptic activities [26]

Aloe vera is also a suitable adsorbent. The salting process would cause the adsorption of some fat that may decrease the fat levels. Aloe vera is a potential adsorbent for agricultural waste at low cost [32]. In her research, Wardani showed that elevated concentrations of aloe vera could increase the fat content of milk [28].

\section{3) Moisture content}

The results of the variance analysis indicated that there was an association between blanching and the different concentrations of aloe solution with the moisture content salted egg. This can be seen in Table 1.

Based on Table 1, the moisture content of the raw salted eggs ranged from $60.71 \pm 0.59$ to $66.79 \pm 5.70 \%$. No difference was caused in the moisture content of the produced salted eggs by the content of aloe vera, which may be because it was also mostly water. The moisture content of aloe vera was $97.42 \%$. In this study, the aloe vera solution was diluted to a concentration of $2-14 \%$, so that the main component of the aloe vera solution was water [27]. Including the aloe vera solution with blanching does not affect the moisture content of the solution.

\section{4) The ash content}

The result of the ash content of raw salted eggs was in the range of $1.78 \pm 0.14$ to $3.09 \pm 0.07 \%$, as shown in Table 1 . The results of the variance analysis showed that there was a real association between blanching and the different concentrations of aloe solution with the ash content. The blanching $(2.67 \pm 0.37 \%)$ and the concentration of aloe vera solution $(2.44 \pm 0.93 \%)$ together would increase the ash content of the salted egg.

The highest ash content (blanching with the $14 \%$ aloe vera solution) was $3.09 \pm 0.07 \%$ from the $\mathrm{A} 2 \mathrm{~B} 3$ treatment. The ash content was affected by the diffusion of the mineral into the eggs during the salting process. Ash content of Mallard duck is $1.12 \pm 0.10 \%$, and Peking duck is $1.13 \pm 0.10 \%$ [33], resulting in increased ash content of 0.66 $1.87 \%$ due in the marinating process. Aloe vera contains nine minerals that are essential for a healthy life. Aloe vera contains calcium, chromium, copper, iron, magnesium, manganese, potassium, sodium and zinc, which are specific to work in combination with each other, along with vitamins and other trace elements [26]. The blanching process hindered the work of enzymes, hormones, aloin, and saponins in the aloe vera solution, thereby easing the process of diffusion of minerals into the egg, so the ash content increased. The higher the concentration of the aloe vera solution with the blanching process, the more minerals contained within, which would lead to more mineral diffusion into the egg at the $14 \%$ aloe vera solution.

The lowest ash content was produced from the A1B3 treatment, with an ash content of $1.78 \pm 0.14 \%$. The $14 \%$ aloe gel solution caused this without blanching, which could bind minerals and cause a decrease of the ash content, including the dominant salt. Andriyanto said that the addition of more enormous amounts of ginger juice caused lower levels of salt and ginger gel, which are capable of encapsulating the salt so that the salinity decreases [4]. This is by the higher aloe vera concentration without blanching reducing the ash content.

\section{5) $\mathrm{NaCl}$ content}

The results of the variance analysis indicated that the blanching treatment and different concentrations of aloe solution had no interaction effect on the $\mathrm{NaCl}$ content. The 
results of the $\mathrm{NaCl}$ content of raw salted egg are shown in Tabel 1.

Based on Tabel 1. $\mathrm{NaCl}$ content of the salted egg albumen ranged from $3.96 \pm 0.09$ to $5.62 \pm 0.23 \%$ with the blanching treatments and different concentrations of aloe vera solution by salting for 9 days. The salt content of albumen gels from duck egg with marinating for 15 to 20 days has a salt content of $5.10 \pm 0.08-6.19 \pm 0.00 \%$ [34]. This was due to the use of the low concentrations of aloe vera solution, between 2 to $14 \%$, in the salting process with and without blanching. Aloe vera gel contains $3.66 \% \mathrm{Na}$ based on the dry matter [16]. Research by Faiz et al. indicated that salting using ginger juice with a concentration of 0 to $50 \%$ did not significantly affect salinity [35]. The salinity of the cooked egg white albumen of salted eggs is $1.92 \pm 0.06 \%$, and the salinity of the yolk is $0.48 \pm 0.27 \%$ [36]. The two-stage marinating process produces a lower salinity in the salted egg albumen (3.64\%) than does the traditional process [37]. The use of maltodextrin in the manufacture of salted yolk reduces salt levels. The lowest salt content of commercial yolks is almost the same as that of salted yolks [38].

Along with this, the higher the concentration of aloe vera solution, the higher the $\mathrm{NaCl}$ content of the raw salted eggs produced. The process of diffusion of salt caused the increased $\mathrm{NaCl}$ levels into the egg through the pores of the shell. Joshi said that Aloe vera barbadensis consists of organic acid salts [39]. Using the blanching solution containing aloe vera could simplify the process of diffusion due to the loss of the biological activity of aloe vera gel.

Based on the research results, the moisture content of raw salted eggs relative to the $\mathrm{NaCl}$ levels was not significantly different. Decreasing the moisture content will increase the $\mathrm{NaCl}$ content of salted eggs, as will increasing the concentration of added garlic oil [40]. $\mathrm{NaCl}$ levels increase with increasing salt concentrations and pressure used in the manufacture of the salted eggs in both albumen and yolks [41]. There was a decrease in salt content with longer marinating and higher temperatures used in the marinating process when using pressure with a salt content of 6.87 and $0.73 \%$ for albumen and yolks [42]

\section{B. Total Phenolic Content and Antioxidant Activity of Raw Salted Egg}

\section{1) Total phenolic content}

The total phenolic content of the raw salted egg is shown in Table 2. The results of the variance analysis indicated that the blanching treatment and different concentrations of aloe solution had a real association with the total phenolic content.

Based on Table 2, the total phenolic content ranged from $0.55 \pm 0.09$ to $0.73 \pm 0.12 \%$, increasing by $0.18 \%$. The highest total phenolic content was found with the A1B3 treatment and was significantly different from other treatments. This was caused by the higher concentration (14\%) aloe vera solution without blanching, such that the aloin had not been inactivated and was measured as part of the total phenols. Anthraquinone derivatives (anthrones and chromones) from aloe vera comprise the phenolic fraction of the sap. The primary sap component is aloin/barbaloin, an anthrone derivative [26]. This is in line with the research conducted by Ruslay, which indicated that the increase of the total phenolic content of salted eggs would be proportional to the increase of concentrations added into the salting solution [43].

The total phenolic content produced by the A1B2 treatment was the lowest but was not significantly different from other treatments except A1B3. The low phenolic level was caused by the low content of anthraquinones (2-8\% aloe vera without blanching) and the process of blanching, which inactivated the aloin. Heating aloe vera gel will result in a loss of biological activity [44].

TABLE II

TOTAL PHENOLIC CONTENT AND ANTIOXIDANT ACTIVITY (\%) OF RAW SALTED EGGS

\begin{tabular}{|c|c|c|c|c|}
\hline \multirow{2}{*}{$\begin{array}{l}\text { Fac- } \\
\text { tor A }\end{array}$} & \multicolumn{3}{|c|}{ Factor B } & \multirow[t]{2}{*}{ Mean } \\
\hline & B1 & $\mathbf{B 2}$ & B3 & \\
\hline \multicolumn{5}{|c|}{ Total phenolic content } \\
\hline A1 & $0.56 \pm 0.01^{\mathrm{b}}$ & $0.59 \pm 0.03^{\mathrm{b}}$ & $0.73 \pm 0.12^{\mathrm{a}}$ & $0.63 \pm 0.09$ \\
\hline $\mathrm{A} 2$ & $0.55 \pm 0.09^{b}$ & $0.62 \pm 0.07^{\mathrm{b}}$ & $0.58 \pm 0.03^{\mathrm{b}}$ & $0.58 \pm 0.03$ \\
\hline Mean & $0.56 \pm 0.01$ & $0.61 \pm 0.02$ & $0.66 \pm 0.10$ & \\
\hline \multicolumn{5}{|c|}{ Antioxidant activity } \\
\hline A1 & $12.76 \pm 0.23$ & $18.01 \pm 7.94$ & $33.29 \pm 4.32$ & $21.35 \pm 10.66^{\mathrm{A}}$ \\
\hline $\mathrm{A} 2$ & $8.09 \pm 1.33$ & $15.00 \pm 5.75$ & $20.19 \pm 3.13$ & $14.43 \pm 6.07^{\mathrm{B}}$ \\
\hline Mean & $10.43 \pm 3.30^{\mathrm{B}}$ & $16.50 \pm 2.13^{\mathrm{B}}$ & $26.74 \pm 9.26^{\mathrm{A}}$ & \\
\hline
\end{tabular}

The antioxidant activity of plant materials closely correlates with the content of phenolic compounds [45]. The Aloe Vera gel extract has been shown to have a total phenolic content of $1.34 \pm 0.87$ grams of CEs/L [10], and the content is $14.26 \pm 0.25 \mathrm{mg} / \mathrm{g}$ from Aloe Barbadensis [46].

The total phenolic content found in this study was much higher than that found in the study by Faiz et al., in which salting using ginger juice at a $75 \%$ concentration did not affect the range of total phenols, which was $0.100 \pm 0.034$ to $0.125 \pm 0.044 \%$, compared to that of the controls, which contained $0.082 \pm 0.030 \%$ [35]. The total phenolic content of the salted eggs increased by $40 \%$ with the addition of $0.04 \%$ white turmeric concentrate $(0.12 \pm 0.010$ to $0.016 \pm 0.010 \%)$ [25].

\section{2) Antioxidant activity}

The antioxidant activity of raw salted egg yolk is shown in Table 2. The results of the variance analysis indicated that the blanching treatment and different concentrations of aloe solution did not affect the antioxidant activities. Blanching of the aloe vera solution significantly affected its antioxidant activity, while the concentration of the aloe solution significantly affected the antioxidant activity.

In Table 2, it can be seen that the antioxidant activity of raw salted egg yolk with aloe vera solution added without blanching was higher than that of eggs produced with blanching. The heating could destroy most of the vitamins in the aloe vera solution that were not resistant to heat, such as vitamin C. Aloe vera contains some important antioxidant 
vitamins such as vitamins A, C, and E [5], [26] as well as polysaccharides and flavonoids [47]. Aloe vera gel contains vitamin $C$ at a concentration of $127.6 / 100 \mathrm{~g}$ and vitamin $\mathrm{E}$ at a concentration of $0.25 \mathrm{mg} / 100 \mathrm{~g}$ [16]. The antioxidant capacity of aloe vera gel decreases at a temperature of 80$90^{\circ} \mathrm{C}$, in addition to a decrease in crude fiber, $\mathrm{Ca}$ and vitamin C [48].

The extract of aloe vera gel inhibits the generation of DPPH radicals in a dose-dependent manner, and its $\mathrm{IC}_{50}$ value, which is defined as the concentration of substrate that causes a 50\% loss of the DPPH activity (color), was found to be $2.9 \pm 0.1 \mu \mathrm{g} / \mathrm{ml}(10 \mu \mathrm{M} \mathrm{CEs})$. A lower value of $\mathrm{IC}_{50}$ indicates greater antioxidant activity of a test substance [11].

Increasing the concentration of aloe vera also enhanced the antioxidant activity (Table 5). Addition of white turmeric concentrate [25] and red galangal extract [49] at $40 \%$ of the salt solution volume increased the antioxidant activity of salted eggs compared to a control at 0 days of storage, with $\mathrm{IC}_{50}$ values changing from $190.86 \pm 0.98$ to $99.80 \pm 0.05 \mathrm{mg} / \mathrm{g}$ and from $192.47 \pm 2.62$ to $79.72 \pm 1.91 \mathrm{mg} / \mathrm{g}$, respectively. These results were contradictory to those of Andriyanto et al., who found that the concentration of cinnamon extract more than 5\% will reduce the antioxidant activity [4]. Results of Duncan's test indicated that treatment B3 had a significant effect and produced the highest antioxidant activity compared to that of other treatments. This was caused by the addition of the aloe vera solution, which contains powerful antioxidants. Aloe vera extract has a higher antioxidant activity than that of the synthetic antioxidant BHT and tocopherol [10]. The salted eggs produced with the $14 \%$ aloe vera solution had an antioxidant activity of $26.74 \pm 9.26 \%$.

The antioxidant activity found in this study was much higher than that found in other studies, with the addition of a $14 \%$ aloe vera solution amounting to antioxidant activity of $33.29 \pm 4.32 \%$. Adriyanto et al. stated that the antioxidant activity found in this study, with a $14 \%$ aloe vera solution yielding $33.29 \pm 4.32 \%$, is much higher than that found in other studies. Moreover, he said that the activity of salted eggs produced with $10 \%$ cinnamon extract was increased by $21.19 \%$ [4]. Suryatno claimed that the antioxidant activity of salted eggs produced with $50 \%$ ginger extract and ten days of salting increased by $12.50 \%$ [3].

\section{Total Plate Count and $\mathrm{pH}$}

\section{1) Total plate count}

Total plate count in the raw salted eggs from the three trials of each factor ranged from $2.13 \pm 0.58$ to $2.30 \pm 0.00 \mathrm{Log}$ CFU/g (Table 3). An analysis of variance showed a significant difference in the total plate count produced from blanching and different concentrations of aloe vera solution.

Duncan's advanced test showed that the A2B3 treatment was not significantly different from the A2B2 treatment, but was significantly different from all other treatments. Treatment A2B3 (14\% aloe vera solution with blanching) had the highest total plate count, with an overall mean of $2.30 \pm 0.00 \mathrm{Log} \mathrm{CFU} / \mathrm{g}$. This may have been because blanching of the aloe vera solution disabled the antibacterial properties of aloin. Aloin has potential as an antimicrobial [14].

Research by Narsih showed that heating to a temperature of $80^{\circ} \mathrm{C}$ for 60 minutes would inhibit aloin in aloe vera [18]. Additionally, blanching serves to inactivate the proteases that will work synergistically with glucomannans to kill bacteria, such that the total plate count increases with the increasing concentration of aloe vera solution. So the antibacterial compound serves to decrease the total plate count of salted egg. Novia research, tannin is an antibacterial compound that increases its content with an increasing evaporation temperature of the gambier liquid waste [50].

TABLE III

Total Plate Count (LOG CFU/G) AND Albumen AND YolK PH OF RaW SALTED EGGS

\begin{tabular}{|c|c|c|c|c|}
\hline \multirow{2}{*}{$\begin{array}{l}\text { Fac- } \\
\text { tor A }\end{array}$} & \multicolumn{3}{|c|}{ Factor B } & \multirow[t]{2}{*}{ Mean } \\
\hline & B1 & B2 & B3 & \\
\hline \multicolumn{5}{|c|}{ Total plate count } \\
\hline $\mathrm{A} 1$ & $2.17 \pm 0.58^{\mathrm{b}}$ & $2.13 \pm 0.58^{\mathrm{b}}$ & $2.13 \pm 0.58^{\mathrm{b}}$ & $2.14 \pm 0.19$ \\
\hline $\mathrm{A} 2$ & $2.13 \pm 0.58^{\mathrm{b}}$ & $2.23 \pm 0.58^{\mathrm{a}}$ & $2.30 \pm 0.00^{\mathrm{a}}$ & $2.22 \pm 0.84$ \\
\hline Mean & $2.15 \pm 0.24$ & $2.18 \pm 0.71$ & $2.27 \pm 1.18$ & \\
\hline \multicolumn{5}{|c|}{ Albumen pH } \\
\hline A1 & $7.35 \pm 0.04^{\mathrm{c}}$ & $7.19 \pm 0.02^{\mathrm{d}}$ & $8.12 \pm 0.09^{\mathrm{b}}$ & $7.55 \pm 0.50$ \\
\hline $\mathrm{A} 2$ & $8.35 \pm 0.05^{\mathrm{a}}$ & $8.40 \pm 0.02^{\mathrm{a}}$ & $8.31 \pm 0.05^{\mathrm{a}}$ & $8.36 \pm 0.05$ \\
\hline Mean & $7.85 \pm 0.71$ & $7.80 \pm 0.86$ & $8.21 \pm 0.14$ & \\
\hline \multicolumn{5}{|c|}{ Yolk pH } \\
\hline A1 & $6.23 \pm 0.05$ & $6.21 \pm 0.06$ & $6.23 \pm 0.10$ & $6.22 \pm 0.01$ \\
\hline $\mathrm{A} 2$ & $6.28 \pm 0.05$ & $6.20 \pm 0.04$ & $6.19 \pm 0.03$ & $6.22 \pm 0.05$ \\
\hline Mean & $6.25 \pm 0.04$ & $6.21 \pm 0.01$ & $6.21 \pm 0.03$ & \\
\hline
\end{tabular}

Note: A1: without blanching, A2: blanching, B1: 2\%, B2: 8\%, and B3: $14 \%$ concentrations of aloe vera solution. Interactions with different superscripts in lowercase differ significantly at $\mathrm{P}<0.05$, respectively.

Yuniati measured 2.66 Log colonies of bacteria per gram in salted eggs that were made using ash for ten days [51]. Andriyanto's results showed a 3.20 Log CFU/g total plate count in salted duck eggs in their control group, but with the addition of $5 \%$ cinnamon extract, the total plate count was reduced to $2.54 \mathrm{Log} \mathrm{CFU} / \mathrm{g}$ [4]. Even if heating the aloe vera solution did degrade the antibacterial properties of aloin,

Treatments A1B2, A1B3, A2B1 produced the lowest total plate count (overall mean 2.13 $\pm 0.58 \mathrm{Log} \mathrm{CFU} / \mathrm{g}$ ) and did not differ significantly from each other or A1B1. Aloe vera's antibacterial properties probably caused the low total plate count produced with these treatments. The content of polyphenolic compounds in the A1B3 treatment was also the highest, which was in line with the total plate count of these salted eggs being the lowest. This was influenced by polyphenolic compounds, which have antibacterial properties [52] and effectively kill bacteria on salted eggs during the salting process.

Aloe juice is a potential antimicrobial, with (grampositive) bacteria affected by its content of tannins, saponins, and flavonoids [13], [53], and gram-negative bacteria are affected by its polysaccharides [16]. Aloe vera contains $4.27 \%$ aloin compounds and $5.43 \%$ saponins [18]. Aloe vera contains saponins, which function as a natural antibacterial with a good ability to kill bacteria [54]. In treatments 
without blanching, proteases remain active and, in the presence of glucomannans, will work together with these compounds to kill bacteria, resulting in lower amounts of colonies formed. The polysaccharides in aloe vera stimulate proteins to enter into the bacterial membrane, puncturing and damaging the protective layer around the fluid and causing the death of the bacteria [24].

Hence, with the resulting low numbers of bacterial colonies forming and the low albumen $\mathrm{pH}$ of raw duck egg, soaking salted eggs in aloe vera could potentially extend the shelf life of these eggs. This is in fact what was discovered by Allismawita, who used a concentrated $50 \%$ aloe vera solution to extend the shelf life of boiled salted eggs to 19 days, with 5.48 $\pm 0.6 \mathrm{Log} \mathrm{CFU} / \mathrm{g}$ bacterial colonies forming after six days [19].

\section{2) Albumen $p H$}

The albumen $\mathrm{pH}$ ranged from $7.19 \pm 0.02$ to $8.40 \pm 0.02$, as seen in Table 3. An analysis of variance showed that there was a significant difference in the $\mathrm{pH}$ for both different temperatures and aloe vera concentrations.

Duncan's advanced test showed that the $\mathrm{pH}$ of the A1B2 treatment ( $8 \%$ aloe vera solution without blanching) was significantly different from that produced by other treatments, having the lowest $\mathrm{pH}$ with an overall mean value of 7.19 \pm 0.02 . The $\mathrm{pH}$ of duck albumen increases during storage due to the evaporation of $\mathrm{CO}_{2}$, and this causes the albumen to become less viscous [55]. Microorganisms more easily contaminate this less viscous albumen. Adamski measured the range of the albumen $\mathrm{pH}$ in duck eggs that were less viscous, with a $\mathrm{pH}$ range of 8.65 (thin albumen) to 8.78 (thick albumen) [56]. The low $\mathrm{pH}$ of eggs produced from the $\mathrm{A} 1 \mathrm{~B} 2$ treatment as a result of an acidic aloe vera solution ( $\mathrm{pH} 5$ ), improving the antibacterial properties.

The highest $\mathrm{pH}$ was found from the A2B2 treatment $(8 \%$ aloe vera solution with blanching), with an overall mean value of $8.40 \pm 0.02$, and this value did not differ significantly with a variation of the aloe vera concentration (cf. A2B1 and A2B3). This lack of difference appears to indicate that the heating process inhibits the acidification activity of aloe vera. However, the $\mathrm{pH}$ values obtained in this study were still lower than that of Novia [1], who measured an albumen $\mathrm{pH}$ of 9.34 after salting raw duck eggs for 8 days. Even the blanched aloe vera solution appears to have some effect on the $\mathrm{pH}$. Marinating Pegagan duck eggs for 2 weeks using palm oil frond ash resulted in an egg white $\mathrm{pH}$ of $9.58 \pm 0.10$, and a decrease in the $\mathrm{pH}$ was produced by adding $10 \%$ liquid smoke, producing a $\mathrm{pH}$ of $9.13 \pm 0.09$ [57]. Salted eggs with the addition of $50 \%$ Curcuma juice in the salting solution increased the $\mathrm{pH}$ from $7.68 \pm 0.13$ (control) to $8.03 \pm 0.07$ [58].

\section{3) Yolk $p H$}

The study of salted eggs by blanching treatment and immersion in aloe vera solution to yolks did not significantly affect the variance with ranges of $6.19 \pm 0.03$ to $6.28 \pm 0.05$. This was by egg yolk texture consisting of spherical granules and embedded flattened porosities, SEM results [59]. Yolk $\mathrm{pH}$ of salted pegagan duck eggs for 2 weeks using palm leaf ash and liquid smoke, also no significant effect with the $\mathrm{pH}$ value of $7.02 \pm 0.13$ to $7.28 \pm$ 0.19 [57].

\section{CONCLUSIONS}

The research process of making salted eggs utilize aloe vera can be concluded that raw salted eggs with herbal effects have been generated by an increase in protein content, total phenolic content, antioxidant activity, and decrease the total plate count. Treatment with without blanching and concentrations $14 \%$ are able to produce salted egg with high protein content $12.41 \pm 0.56 \%$, fat content $16.80 \pm 0.56 \%$, moisture content $66.79 \%$, ash content $1.78 \pm 0.14 \%$, total phenolic content $0.73 \pm 0.12$, antioxidant activity $33.29 \pm 4.32 \%, \mathrm{NaCl}$ content $5.32 \%$, albumin $\mathrm{pH} 8.12 \pm 0.09$, and total plate count $2.13 \pm 0.58 \mathrm{Log} \mathrm{CFU} / \mathrm{g}$.

\section{ACKNOWLEDGMENT}

Awards and acknowledgments were addressed to those who have supported the implementation of the competitive research grants, primarily to Directorate General of Research and Development, Ministry of Research, Technology and Higher Education as funding through Research Grant Number: 020/SP2H/LT/DRPM/II/2016, dated February 17, 2016, then Rector Andalas University, Chairman of LPPM Unand, and Dean of Animal Science Faculty.

\section{REFERENCES}

[1] D. Novia, S. Melia, I. Juliyarsi, "Utilization of ash in the salting process on mineral content raw salted eggs," Asian J. Poult. Sci., vol. 8(1), pp. 1-8. 2014.

[2] D. Novia, I. Juliyarsi, A. Sandra, Yuherman, R. Muhammad, "Soaking salted egg in gambier liquid waste inhibit bacterial growth," Pak. J. Biol. Sci., vol. 17(3), pp. 424-42., 2014.

[3] Suryatno, H., Basito dan E. Widowati, "A study on organoleptic, antioxidant activity, total phenol on a duration of aging variation of salty eggs making added by ginger extract (Zingiber officinale Roscoe)," Jurnal Teknosains Pangan, vol. 1(1), pp. 118-125. 2012.

[4] A. Andriyanto, M. A. M. Andriani, E. Widowati, "The influenced of cinnamon extract addition to a sensory characteristic, antioxidant activity and antibacterial activity on salted eggs during storage in method wet salting," J.Teknosains Pangan, vol. 2(2), pp. 13-20. 2013.

[5] B. Joseph, S. J. Raj, "Pharmacognostic and phytochemical properties of Aloe vera Linn-an overview," IJPSRR, vol. 4(2), pp. 106-110. 2010.

[6] Council of Europe, Risk Profile Aloe vera, Cas No.85507-69-3', p. 124. 2013.

[7] N. Soltanizadeh, H. Ghiasi-Esfahani, "Qualitative improvement of low meat beef burger using Aloe vera," Meat Science, vol. 99, pp. 75-80. 2015.

[8] J. M. Vieira, M. L. Flores-López, D. J. de Rodríguez, M. C. Sousa, A. A. Vicente, J. T. Martins, "Effect of chitosan-Aloe vera coating on postharvest quality of blueberry (Vaccinium corymbosum) fruit," Postharvest Biol. Technol., vol. 116, pp. 88-97. 2016.

[9] FDA, Message on the Internet about HACCP Inspection at Aloe Product Manufactures. 2000.

[10] K. R. Anilakumar, K. R. Sudarshanakrishna, G. Chandramohan, N. Ilaiyaraja, F. Khanum, A.S. Bawa, "Effect of Aloe vera gel extract on antioxidant enzymes and azoxymethane-induced oxidative stress in rats," Indians J. Exp. Biol, vol. 48(8), pp. 837-842. 2010.

[11] S. Mazzulla1, S. Sesti, A. Schella, I. Perrotta, A. Anile, S. Drogo, "Protective effect of aloe vera (Aloe barbadensis Miller) on erythrocytes anion transporter and oxidative change," Food and Nutrition Sciences, vol. 3, pp. 1697-1702. 2012.

[12] N. L.Ariani, A. Gofur, D. Listyorini, H. Susanto, and Y. Handaya, "Effect of Aloe vera gel on a superoxide dismutase (sod) level in streptozotocin (stz)-induced diabetic Wistar rattus novergicus liver," KnE Life Sciences, vol. 2, pp. 51-57. 2015.

[13] S. Arunkumar, M. Muthuselram, "Analysis of phytochemical constituents and antimicrobial activities of Aloe vera $\mathrm{L}$ against clinical pathogens," WJAS, vol. 5(5), pp. 572-576. 2009. 
[14] S. Agarwal, T. R. Sharma, "Multiple biological, activities of Aloe barbadensis (Aloe vera): an overview," Asian Journal of Pharmacy \& Life Science, vol. 1 (2), pp. 195-205. 2011.

[15] Bhalang, K, and K. Tompkins. Polysaccharides from Aloe Vera and Oral Ulcerations, p. 2137-2150, http://link.springer.com /content /pdf/10.1007/978-3-319-16298-0_75.pdf, 2015.

[16] D. I. Sánchez-Machado, J. López-Cervantes, R. Sendón, A. SanchesSilva, "Aloe vera: ancient knowledge with new frontiers," Trends Food Sci. Technol., pp. 1-25. 2017.

[17] G. Luta, B.H. McAnalley, "Aloe vera: chemical composition and methods used to determine its presence in commercial products," GlycoSci Nutr, vol. 6(4), pp. 1-12. 2005.

[18] Narsih, S. Kumalaningsih, Wignyanto S. Wijana, "Identification of aloin and saponin and chemical composition of volatile constituents from Aloe vera (L) Peel,", J. Agric Food Tech., vol. 2(5), pp. 79-84. 2012

[19] Allismawita, D. Novia, I. Putra, "Evaluation of bacterial colony forming and shelf life salted eggs with soaked in Aloe vera (Aloe vera barbadensis Miller)," J. Peternakan Indonesia, vol. 16(2), pp. 71-77. 2014.

[20] Yenrina, R., Metode Analisis Bahan Pangan dan Komponen Bioaktif, 1st ed, Andalas University Press, Padang-Indonesia, 2015.

[21] Sayuti, K., R. Yenrina, Antioksidan Alami dan Sintetik, 1st ed, Andalas UniversityPress, Padang-Indonesia, 2015.

[22] Cara Uji Mikrobiologi-Bagian 3: Penentuan Angka Lempeng Total (ALT) pada Produk Perikanan, Badan Standardisasi Nasional (BSN), SNI 01-2332.3-2006.

[23] S. Kumar, and J.P. Yadav, "Ethnobotanical and pharmacological properties of aloe vera: A review," Jornal of Medicinal Plant Research., vol. 8(48), pp. 1387-1398. 2014.

[24] A.P. Wardhanu, "Potensi Lidah Buaya Pontianak (Aloevera chinensis Linn) sebagai Bahan Baku Industri Berbasis Sumber Daya Lokal, Teknologi Industri Pertanian. Pascasarjana. Unibraw. Malang, 2009.

[25] Mu'addimah, I. Thohari, D. Rosyidi, "The addition of white turmeric (Curcuma zedoaria) concentrated base on quality antioxidant activity, total phenol, protein content and salt content of salted egg," JITEK, vol. 10(1), pp. 46-53, April 2015.

[26] S. Agarwal, T. R. Sharma, "Multiple biological, activities of Aloe barbadensis (Aloe vera): an overview," Asian Journal of Pharmacy \& Life Science, vol. 1 (2), pp. 195-205. 2011.

[27] M. Ahmed and F. Hussain, "Chemical composition and biochemical activity of aloe vera (Aloe barbadensis Miller) leave," IJCBS, vol. 3, pp. 29-33. 2013.

[28] I. M. P. Wardani, Nardani, Sumardi, M. H. Bagus, "Effect of Aloe vera addition (Aloe vera $s p$ ) on physical and chemical properties of fresh cow milk and soy milk," JBKT, vol. 1(1), pp. 80-87. 2013.

[29] Nuruzzakiah, H. Rahmatan, D. Syafrianti, "Pengaruh kosentrasi garam terhadap kadar protein dan kualitas organoleptik telur bebek," Jurnal Ilmiah Mahasiswa Pendidikan Biologi, vol. 1(1), pp. 1-9. 2016.

[30] A. Baruah, M. Bordoloi, H.P.D. Baruah, "Aloe vera : A multiporpose industrial crop," Ind. Crop Prod., vol. 94, pp. 951-963. 2016.

[31] J. H. Hamman, "Review Composition and applications of Aloe vera leaf gel," Molecules, vol. 13, pp. 1599-1616. 2008.

[32] C. Pragathiswaran, S. Sibi, P. Sivanesan, "Adsorption of hexavalent chromium from aqueous solutions by aloe vera leaf," IJRPC, vol. 3 (4), pp. 876-880. 2013.

[33] F. Al-Obaidi, S.M.J. Al-Shadeedi, "Comparison study of egg morphology, component and chemical composition of Mallard duck and Peking duck," J. Genet. Environ. Resour. Conserv., vol. 4(1), pp. 5-9, 2016.

[34] T.H. Quan, S. Benjakul, "Compositions, protease, inhibitor and gelling property of duck egg albumen as affected by salting," Korean J. Food Sci. An., vol. 38(1), pp. 14-25, February. 2018.

[35] H. Faiz, I. Thohari, Purwadi, "Pengaruh penambahan sari temulawak (Curcuma xanthorrhiza) terhadap total fenol, kadar garam, kadar lemak dan tekstur telur asin," Jurnal Ilmu-Ilmu Peternakan, vol. 24(3), pp. 38 - 44. 2014.

[36] Nurliyani, A. Hartawan, Y.A. Nugroho, Indratiningsih, "The characteristics of salted chicken and duck egg by using traditional roasting," Proceedings The $6^{\text {th }}$ ISTAP, Oktober 20-22, Yogyakarta, Indonesia, 2015.
[37] H. Su, R. Yang, W. Zhao, X. Hua, W. Zhang, "Preparation of salted eggs with low salt," Food \& Machinery, vol. 1, pp. 050. 2015.

[38] T.H. Wang, "Salting yolk directly using fresh duck egg yolks with salt and maltodextrin," J-STAGE Advance Publication, doi: 10.2141/jpsa.0160027. 2016

[39] S. P. Joshi, "Chemical constituents and biological activity of Aloe barbadensis: a review," JMAPS, vol. 20, pp. 768-773. 1998.

[40] P. W. Harlina, R. Ma. M. Shahzad, F. Geng, Q. He. L. Wang, S. Qiu. N. Ding, "Effect of garlic oil on lipid oxidation, fatty acid profiles, and microstructure of salted duck eggs," J. Food Process. Preserv., vol. 39, pp. 2897-2911. 2015.

[41] Rukmiasih, N. Ulupi, W. Indriani, "Physical, chemical and organoleptic characteristics of salted eggs by salting with pressure level and salt concentration different,"Jurnal Ilmu Produksi dan Teknologi Hasil Pertanian, vol.03(3), pp. 142-145, October 2015.

[42] N. Yang, Y. Jin, Y. Xu, Y. Bin, X Xu, "Effect of pressure cooking on physicochemical properties of salted eggs," RSC Adv. vol. 6, pp.97089-97095. 2016.

[43] S. F. Ruslay, Abas, K. Shaari, Z. Zainal, Maulidina, H. Sirat, D. A. Israf dan N. H. Lajis, "Characterization of the components present in the active fractions of health gingers (Curcuma xanthorrhiza and Zingiber zerumbet) by HPLCDAD-ESIMS," Food Chem., vol. 104, pp. 1183-1191. 2007.

[44] C. T. Ramachandra, P. S. Rao, "Processing of Aloe vera leaf gel: A Review," AJABS, vol. 3(2), pp. 502-510. 2008.

[45] M. Skerget, P. Kotnik, M. Hadolin, A. R. Hras, M. Si-monic, and Z Knez, "Phenols, proanthocyanidins, flavones and flavonols in some plant materials and their antioxidant activities," Food Chem., vol 89(2), pp. 191-198. 2005.

[46] S. K. Sonam, A. Tiwari, "Phytochemical evaluation of different aloe species," Int. J. Chem. Pharm. Anal., vol. 3, pp. 2-8, Sep. 2016.

[47] Y. Hu, J. Xu Q. Hu, "Evaluation of Antioxidant Potential of Aloe vera (Aloe barbadensis Miller) Extracts," J. Agric. Food Chem., vol. 51(26), pp. 7788-7791. 2003.

[48] M. Miranda, H. Maureira, K. Rodriguez, A. Vega-Galvez, "Influence of temperature on the drying kinetics, physicochemical properties, and antioxidant capacity of Aloe Vera (Aloe Barbadensis Miller) gel," J. Food Eng. vol. 91(2), pp. 297-304. 2009

[49] F. Sholehah, I.Thohari, F. Jaya, "The addition of red galangal extract (Alpinia purpurata K.Schum) and different storage in salted egg to total microorganism, antioxidant activity, water activity, and texture," JITEK, vol. 10(2), pp.18-27, October 2015

[50] D. Novia, E. Vebriyanti and H.F. Hakim, "Evaluation of Heating the Gambier Liquid Waste on the Quality of Raw Salted Eggs," IJPS, vol. 16(9), pp. 369-373. 2017.

[51] H. Yuniati, "The effect of using the ash and the red brick powder in making the salted eggs to the microbial content of the eggs," $P G M$, vol. 34(2), pp. 131-137. 2011.

[52] O. A. Ojiako, C. U. Igwe, "The nutritive, anti-nutritive and hepatotoxic properties of Trichosanthes anguina (snake tomato) fruits from Nigeria," PJN, vol. 7(1), pp. 85-89. 2008.

[53] S. Alemdar, S. Agaoglu, "Investigation of in-vitro antimicrobial activity of aloe vera juice," J. Anim. Vet. Adv., vol. 8(1), pp. 99-102. 2009 .

[54] A. Gusviputri, N. P. S. Melina, Aylianawati, I. Indraswati, "Pembuatan sabun dengan lidah buaya (Aloe vera) sebagai antiseptic alami," Widya Teknik, vol. 12(1), pp. 11-21. 2013.

[55] Z. Wulandari, "Physicochemical properties and total plate count of salted duck egg produced by pressure method during storage," Media Peternakan, vol. 27(2), pp. 38-45, 2004.

[56] M. Adamski, Z. Bernacki, J. Kuzniacka, "Changes in the Biological Value of Duck Eggs Defined by Egg Quality," Folia Biol-Krakow, vol. 5(3), pp. 107-114. 2005.

[57] F. Yosi, N. Hidayah, Jurlinda, M.L. Sari, "The physical quality of salted Pegagan duck egg using palm oil fronds ash and liquid smoke as a curing agent," Buletin Peternakan, vol. 40(1), pp. 66-74. 2016.

[58] M.A. Kurniawan, I. Thohari, L.E. Radiati, "Pengaruh penambahan sari temulawak (Curcuma xanthorrhiza Roxb) terhadap kadar asam lemak bebas (FFA), $\mathrm{pH}$ dan kadar kurkumin pada telur asin," JIIP, vol.25(1), pp. 8-15, 2015.

[59] L. Xu, Y. Zhao, M. Xu, Y. Yao, X. Nie, H. Du, Tu Y.G., Effects of salting treatment on the physicochemical properties, textural properties, and microstructures of duck eggs, PLoS One, vol. 12(8), pp. 1-17, Aug. 2017. 